\title{
Pengaruh Konflik Peran dan Ambiguitas Peran Terhadap Komitmen Independensi Auditor Internal
}

\author{
Victorinus Laoli ${ }^{1}$, Sonitehe Gea $^{2}$ \\ ${ }^{1}$ Sekolah Tinggi Ilmu Ekonomi Pembangunan Nasional, Gunungsitoli, e-mail: vic.laoli@gmail.com \\ ${ }^{2}$ Sekolah Tinggi Ilmu Ekonomi Pembangunan Nasional, Gunungsitoli, e-mail: sonihakhoda@gmail.com
}

\section{ARTICLE INFO}

Article history:

Received 30 Mei 2020

Received in revised form 3 Juni 2020

Accepted 30 Juni 2020

Available online 1 Juli 2020

\begin{abstract}
This study aims to assess and identify the influence of role conflict and role ambiguity and the independence commitment of internal auditors to work at the Regional Development Bank of North Sumatra, Nias Islands Region. Determination of respondents is done by purposive sampling, which is a sampling technique based on certain criteria. The number of questionnaires distributed was 35 questionnaires. This study uses simple linear regression. The results of the analysis in this study indicate that the role conflict and the ambiguity of each affect.
\end{abstract}

Keywords: role conflict, role ambiguity, internal auditor independency

\section{Pendahuluan}

Auditor internal hendaknya dapat mempertahankan sikap independen walaupun merupakan karyawan yang digaji oleh perusahaan, auditor internal sangat bergantung pada organisasi tempat mereka bekerja sebagai pihak pemberi kerja. Fenomena tersebut seolah-olah memperlihatkan bahwa auditor internal tidaklah independen. Namun jelas sikap independen harus dipertahankan oleh auditor internal sebagai bentuk tanggung jawab kepada publik dan profesi. Selain itu jika auditor internal tidak independen dalam melaksanakan fungsinya maka tidak ada nilai tambah yang diberikan auditor internal kepada organisasi tempatnya bekerja. Menurut Standar Profesi Audit Internal (SPAI) (2004), auditor internal memberikan nilai tambah bagi organisasi dengan cara meningkatkan peluang untuk mencapai tujuan organisasi, mengidentifikasi perbaikan operasi, dan atau mengurangi melalui jasa assurance dan jasa konsultasi. Independensi auditor internal juga diatur di dalam standar atribut yang terdapat di dalam SPAI. Diharapkan dengan memelihara standar atribut auditor internal dapat menjalankan tanggung-jawabnya.

Perubahan peran yang dialami oleh auditor internal membuat mereka rawan mengalami konflik peran. Menurut Mohr et al. dalam Hutami (2012), konflik peran merupakan suatu pikiran, pengalaman, atau persepsi dari pemegang peran (role incumbent) yang diakibatkan oleh terjadinya dua atau lebih harapan peran (role expectation) secara bersamaan, sehingga timbul kesulitan untuk melakukan kedua peran tersebut dengan baik dalam waktu yang bersamaan. Pendapat ini sesuai dengan yang diungkapkan oleh Rizzo et al. dalam Ahmad dan Taylor (2009) bahwa konflik peran muncul ketika ada berbagai tuntutan dari beberapa sumber yang 
menyebabkan karyawan menjadi kesulitan dalam menentukan tuntutan apa yang harus dipenuhi tanpa membuat tuntutan lain diabaikan. Pada tahap peran katalis, auditor menjalankan beberapa tugas sekaligus di dalam perusahaan yaitu melakukan audit dan peran dalam memberikan jasa konsultasi. Dalam peran audit, auditor internal harus menjaga independensi dengan tidak mendasarkan pertimbangan auditnya pada objek pemeriksaan, tetapi dalam peran konsultasi, auditor internal harus bekerja sama dan membantu objek pemeriksaan. Kedua tuntutan profesi ini akan sulit untuk dipenuhi secara bersamaan sehingga akan menimbulkan konflik peran (Ahmad dan Taylor, 2009). Konflik peran yang dialami oleh auditor dapat merusak independensi dan kemampuan auditor untuk melakukan audit yang wajar (Koo dan Sim, 1999).

Perkembangan kegiatan operasional suatu organisasi dapat menimbulkan ambiguitas peran auditor internal. Menurut Kahn et al. (dalam Beauchamp et al. 2004) ambiguitas peran adalah suatu keadaan ketika informasi yang berkaitan dengan suatu peran tertentu kurang atau tidak jelas. Kondisi yang kompleks dan perubahan dalam lingkungan operasional auditor internal, termasuk kompleksitas dan perubahan peraturan dan teknologi, dapat meningkatkan kemungkinan terjadinya ambiguitas peran. (Ahmad dan Taylor, 2009). Menurut Sawyer dan Dittenhofer dalam Ahmad dan Taylor (2009), penyebab terjadinya ambiguitas peran dalam lingkungan auditor internal adalah bahwa auditor internal mungkin melakukan investigasi internal dengan kondisi proses operasional yang belum dikenali, kompleks, dan semakin meluas, serta individu yang berada dalam objek pemeriksaan berbicara dalam bahasa dan menggunakan istilah yang asing bagi pemahaman auditor internal. Sekarang ini perusahaan cenderung untuk beroperasi dengan teknologi yang semakin canggih dan terkadang ada perubahan standar profesi dengan aturan perusahaan. Perubahan mendasar tersebut mengakibatkan lingkungan operasi organisasi menjadi semakin kompleks dan mengakibatkan auditor internal kesulitan untuk melakukan tugas auditnya atau menerapkan standar profesional dengan kejelasan yang kurang memadai. Kahn et al. dalam Ahmad dan Taylor (2009) mengemukakan bahwa ambiguitas peran juga dapat meningkatkan kemungkinan seseorang menjadi merasa tidak puas dengan perannya, mengalami kecemasan, memutarbalikkan fakta, dan kinerjanya menurun. Oleh sebab itu, auditor internal yang menghadapi ambiguitas peran kemungkinan sulit untuk menjaga komitmen mereka untuk tetap bersikap independen (Ahmad dan Taylor, 2009).

Penelitian mengenai pengaruh konflik peran dan ambiguitas peran terhadap komitmen independensi auditor internal pernah dilakukan oleh Ahmad dan Taylor (2009). Penelitian tersebut menggunakan sampel auditor internal yang diperoleh dari database Institute of Auditor Internals Malaysia.Tujuan dari penelitian tersebut adalah untuk mengembangkan ukuran-ukuran konsep komitmen independensi, konflik peran, dan ambiguitas peran dalam konteks lingkungan kerja auditor internal, dengan maksud untuk memberikan bukti empiris mengenai pengaruh konflik peran dan ambiguitas peran beserta dimensinya terhadap komitmen independensi auditor internal. Dalam mengukur komitmen independensi responden, Ahmad dan Taylor mengembangkan dimensi komitmen independensi menggunakan dimensi komitmen organisasi milik Porter et al. yang dikembangkan oleh Aranya et al. menjadi komitmen profesional, hal tersebut dilakukan karena tidak atau belum ditemukannya alat ukur yang sesuai di dalam literatur audit. Sedangkan untuk mengukur konflik peran dan ambiguitas peran Ahmad dan Taylor menggunakan skala milik Rizzo et al. yang sudah disesuaikan dengan literatur audit.

Motivasi peneliti untuk mereplikasi penelitian yang dilakukan oleh Lusius Kharismawan Sindudisastra dan Rustiana pada tahun 2014 dikarenakan Lusius Kharismawan Sindudisastra dan Rustiana dalam penelitiannya menggunakan sampel auditor internal yang bekerja di Bank Perkreditan Rakyat yang ada di Daerah Istimewa Yogyakarta, sehingga penelitian ini masih memungkinkan untuk dilakukan di daerah lain dengan menggunakan sampel auditor internal lembaga keuangan bank yang berbeda. Motivasi selanjutnya karena peneliti masih jarang menemukan penelitian yang mengangkat topik independensi auditor internal 
terutama pada lembaga keuangan bank. Para peneliti lebih sering untuk mengangkat topik independensi auditor internal pada pemerintah.

\section{Kerangka Teoritis dan Pengembangan Hipotesis}

Konflik peran merupakan kondisi dari pemegang peran yang diakibatkan oleh terjadinya dua atau lebih harapan peran secara bersamaan, sehingga timbul kesulitan untuk melakukan kedua peran tersebut dengan baik dalam waktu yang bersamaann (Mohr et al. dalam Hutami, 2010). Konflik peran terjadi saat munculnya peran-peran yang saling bertentangan yang harus dilakukan oleh individu sebagai anggota dalam sebuah organisasi (Koo dan Sim, 1998). Hal itu mengakibatkan individu yang mengalami konflik peran kesulitan untuk membuat keputusan yang tepat mengenai bagaimana menjalankan peran-peran tersebut dengan baik. Dalam menjalankan tugasnya sebagai pegawai di bank, auditor internal akan berhubungan dengan bagian atau pegawai lainnya. Sebagai individu yang memiliki peran yang berbeda, maka hubungan tersebut memicu timbulnya konflik.

Konflik peran yang dialami oleh auditor dapat merusak independensi dan kemampuan auditor untuk melakukan audit yang wajar (Koo dan Sim, 1999). Apabila auditor mencoba untuk tetap mempertahankan sikap profesional mereka, maka akan membahayakan posisi auditor internal tersebut, sehingga auditor menjadi rentan terhadap tekanan dari manajemen dan mengakibatkan menurunnya komitmen independensi (Koo dan Sim, 1999). Penelitian yang dilakukan oleh Hutami (2012) membuktikan bahwa terdapat pengaruh negatif konflik peran terhadap komitmen independensi auditor internal. Penelitian yang dilakukan oleh Ahmad dan Taylor (2009) juga menunjukkan bahwa konflik peran berpengaruh negatif terhadap komitmen independensi auditor internal yang terdafar di bursa efek Malaysia. Berdasarkan teori yang ada dan penelitian sebelumnya maka:

H1 : Konflik peran berpengaruh negatif terhadap komitmen independensi auditor internal.

Pengertian dari ambiguitas peran adalah keadaan ketika informasi yang berkaitan dengan suatu peran tertentu kurang atau tidak jelas (Kahn et al. dalam Beauchamp et al. 2004). Siguaw et al. dalam Adi (2012) mengatakan bahwa ambiguitas peran bisa terjadi akibat job description yang tidak tertulis atau tidak dijelaskan dengan rinci serta tidak adanya standar kerja yang jelas. Kahn et al. (dalam Ahmad dan Taylor, 2009) mengemukakan bahwa ambiguitas peran dapat meningkatkan kemungkinan seseorang menjadi merasa tidak puas dengan perannya, mengalami kecemasan, memutarbalikkan fakta dan kinerjanya menurun. Menurut Bhuian et al. dalam Adi (2012) ketika karyawan mengalami ambiguitas peran maka mereka akan cenderung untuk berkinerja rendah. Oleh sebab itu, auditor internal yang menghadapi ambiguitas peran kemungkinan sulit untuk menjaga komitmen mereka untuk tetap bersikap independen. (Ahmad dan Taylor, 2009). Penelitian yang dilakukan oleh Hutami (2012) membuktikan bahwa terdapat pengaruh negatif ambiguitas peran terhadap komitmen independensi Auditor Internal Pemerintah Daerah Kota Semarang. Hasil dari penelitian Ahmad dan Taylor (2009) menunjukkan bahwa ambiguitas peran dapat berpengaruh negatif terhadap komitmen independensi auditor internal. Berdasarkan teori yang ada dan penelitian sebelumnya maka :

$\mathrm{H} 2$ : Ambiguitas peran berpengaruh negatif terhadap komitmen independensi auditor internal.

\section{Metode Penelitian}

Populasi dalam penelitian ini adalah seluruh auditor internal yang bekerja di bank pembangunan daerah sumatera utara wilayah kepulauan nias. Sampel diambil dengan menggunakan metode nonprobabilitas (secara tidak acak) berdasarkan kriteria (purposive sampling). Kriteria yang digunakan dalam penelitian ini adalah auditor internal yang sudah bekerja lebih atau selama 2 (dua) tahun dan sudah berposisi sebagai auditor internal lebih dari atau selama 2 (dua) tahun.

Di dalam penelitian ini terdapat variabel konflik peran dan ambiguitas peran sebagai variabel independen, dan variabel komitmen independensi auditor internal sebagai variabel dependen. Independensi didefinisikan sebagai bebas dari segala kondisi yang dapat mengancam

JURNAL ILMIAH KOMPUTERISASI AKUNTANSI Vol. 13, No. 1, Juli 2020: $10-15$ 
objektivitas atau bentuk objektivitas (The International Standards forThe Professional Practices of Internal Auditing, 2006).

Untuk mengukur variabel komitmen independensi digunakan dimensi komitmen organisasi milik Porter et al. (1974 dalam Ahmad dan Taylor, 2009) yang dikembangkan kembali oleh Aranya et al. (1981 dalam Ahmad dan Taylor, 2009) menjadi komitmen profesional yaitu: keyakinan kuat atas nilai-nilai, kemauan untuk berusaha keras seperti yang diharapkan, dan keinginan individu yang kuat. Dimensi komitmen profesional tersebut dikembangkan lagi oleh Ahmad dan Taylor untuk mengukur dimensi komitmen independensi dalam penelitian ini yang terdiri dari : (i) Keyakinan kuat dan penerimaan kode etik profesional berkaitan dengan nilai independensi profesi; (ii) Kemauan untuk berusaha keras seperti yang diharapkan dalam rangka memenuhi prinsip dasar profesi untukx menjaga independensi; (iii) Keinginan individu yang kuat untuk bersikap independen sepanjang waktu.

Instrumen komitmen independensi meliputi 10 item pernyataan yang dikembangkan dari lingkup 3 dimensi di atas. Berdasarkan skala Likert 7 poin, Skor tertinggi (skor 7) menunjukkan sikap sangat setuju yang berarti bahwa auditor mempunyai komitmen independensi yang sangat tinggi dan skor terendah (skor 1) menunjukkan sikap sangat tidak setuju yang berarti bahwa auditor mempunyai komitmen independensi yang sangat rendah. Namun ada 3 item pernyataan yang dikodekan terbalik, yaitu item pernyataan pada kolom ke dua.

Pengertian konflik peran adalah kondisi dari pemegang peran yang diakibatkan oleh terjadinya dua atau lebih harapan peran secara bersamaan, sehingga timbul kesulitan untuk melakukan kedua peran tersebut dengan baik dalam waktu yang bersamaan. (Mohr et al. dalam Hutami, 2010). Untuk mengukur konflik peran, digunakan dimensi konflik peran yang diperkenalkan oleh Rizzo et al. yang dikembangkan dan disesuaikan dengan literatur audit internal oleh Ahmad dan Taylor (2009) yaitu sebagai berikut yaitu (1) inter-role conflict (2) intrasender role conflict, (3) personal role conflict.

Instrumen konflik peran meliputi 11 item pernyataan yang dikembangkan dari lingkup 3 dimensi di atas. Berdasarkan skala Likert 7 poin, Skor tertinggi (skor 7) menunjukkan sikap sangat setuju dan skor terendah (skor 1) menunjukkan sikap sangat tidak setuju. Skor yang tinggi mengindikasikan adanya konflik peran yang sangat tinggi dan skor yang rendah mengindikasikan adanya konflik peran yang sangat rendah.

Pengertian ambiguitas peran adalah keadaan ketika informasi yang berkaitan dengan suatu peran tertentu kurang atau tidak jelas (Kahn et al. dalam Beauchamp et al. 2005). Untuk mengukur ambiguitas peran digunakan 6 dimensi yang diperkenalkan oleh Rizzo et., al dalam Ahmad dan Taylor (2009), yaitu (1) garis-garis pedoman (guidelines), (2) tugas (task), (3) wewenang (authorithy), (4) tanggung jawab (responsibilities), (5) standar-standar (standards), dan (6) waktu (time).

Instrumen ambiguitas peran berbentuk pernyataan yang terdiri dari: 5 item untuk dimensi pedoman, 4 item untuk dimensi tugas, 3 item untuk dimensi wewenang, 3 item untuk dimensi tanggung jawab, 3 item untuk dimensi standar, dan 3 item untuk dimensi waktu ini dinyatakan dalam kondisi tidak adanya ambiguitas peran. Berdasarkan skala Likert 7 poin, skor 7 menunjukkan adanya ambiguitas peran yang sangat rendah dan skor 1 menunjukkan adanya ambiguitas peran yang sangat tinggi.

\section{Hasil dan Pembahasan}

Hasil analisis regresi linear sederhana untuk hipotesis I adalah: 
Tabel 1.

Hasil Analisis Regresi Aspek Konflik Peran

\begin{tabular}{lllll}
\hline Variabel & $\beta$ & t hitung & P/Sig & Keterangan \\
\hline Constanta & 6,318 & 25,927 & 0,00 & Sig \\
Konflik Peran & $-0,175$ & $-2,373$ & 0,026 & Sig \\
\hline
\end{tabular}

Berdasarkan perhitungan, persamaan garis regresi linier sederhananya adalah :

$\mathrm{Y}=6,318-0,175 \mathrm{X} 1$

Hasil analisis regresi pada variabel konflik peran diperoleh nilai probabilitas (p) $0,026 \leq$

0,05 dengan koefisien regresi $-0,175$. Berdasarkan analisis regresi tersebut dapat disimpulkan bahwa semakin tinggi konflik peran yang dimiliki seorang auditor internal maka komitmen untuk menjaga independensi akan menurun. Konsisten dengan penelitian Ahmad dan Taylor (2009) dan Hutami (2012).

Sedangkan hasil analisis regresi linear sederhana untuk hipotesis II adalah:

Tabel 2.

Hasil Analisis Regresi Aspek Ambiguitas Peran

\begin{tabular}{lllll}
\hline Variabel & $\beta$ & t hitung & P/Sig & Keterangan \\
\hline Constanta & 7,057 & 15,168 & 0,00 & Sig \\
Ambiguitas & $-0,536$ & $-2,796$ & 0,01 & Sig \\
\hline
\end{tabular}

Berdasarkan perhitungan, persamaan garis regresi linier sederhananya adalah :

$\mathrm{Y}=7,057-0,536 \mathrm{X} 2$

Hasil analisis regresi pada variabel ambiguitas peran diperoleh nilai probabilitas (p) $0,01 \leq 0,05$ dengan koefisien regresi $-0,533$. Berdasarkan analisis regresi tersebut dapat disimpulkan bahwa semakin tinggi ambiguitas yang dimiliki seorang auditor internal maka komitmen untuk menjaga independensi akan menurun. Konsisten dengan penelitian Ahmad dan Taylor (2009) dan Hutami (2012).

\section{Simpulan}

Berdasarkan hasil analisis data yang telah dilakukan secara keseluruhan dari penelitian mengenai konflik peran dan ambiguitas peran auditor internal di Bank Pembangunan Daerah Sumatera Utara Wilayah Kepulauan Nias maka diambil beberapa kesimpulan. Kesimpulan yang pertama, konflik peran berpengaruh secara negatif terhadap komitmen independensi. Kesimpulan tersebut berdasarkan uji statistik yang menunjukkan bahwa pengujian H1 dengan regresi linier sederhana dengan tingkat signifikansi $(\alpha)$ sebesar 0,5 menghasilkan t hitung sebesar $-2,373$ dan probabilitas sebesar 0,026 dengan koefisien regresi $-0,175$. Karena probabilitas konflik peran $\leq 0,05$ dengan koefisien regresi negatif maka hipotesis penelitian yang menyatakan bahwa variabel independen mempengaruhi variabel dependen secara negatif, diterima. Apabila konflik peran mengalami kenaikan maka komitmen independensi akan mengalami penurunan. Dari hasil penelitian ini dapat disimpulkan apabila seorang auditor internal mengalami konflik peran maka komitmen independensi auditor internal tersebut akan menurun. Kesimpulan yang kedua, ambiguitas peran berpengaruh secara negatif terhadap komitmen independensi. Kesimpulan tersebut berdasarkan pada hasil uji statistik yang menunjukkan bahwa pengujian $\mathrm{H} 2$ dengan regresi linier sederhana dengan tingkat signifikansi $(\alpha)$ sebesar 0,5 menghasilkant hitung sebesar 2,796 dan probabilitas sebesar 0,010 dengan koefisien regresi -0,533. Karena probabilitas ambiguitas peran $\leq 0,05$ dengan koefisien regresi negatif maka hipotesis penelitian yang menyatakan bahwa variabel independen mempengaruhi variabel dependen secara negatif, diterima. Artinya apabila ambiguitas peran mengalami kenaikan maka komitmen independensi

JURNAL ILMIAH KOMPUTERISASI AKUNTANSI Vol. 13, No. 1, Juli 2020 : $10-15$ 
akan mengalami penurunan. Dari hasil penelitian ini dapat disimpulkan apabila seorang auditor internal mengalami ambiguitas peran maka komitmen independensi auditor internal tersebut akan menurun.

\section{Daftar Pustaka}

[1] Adi. Ignatius Tyassangka. Pengaruh Budaya Organisasi, Gaya Kepemimpinan, Ambiguitas Peran dan Kompensasi Kerja Terhadap Kepuasan Kerja Pegawai Direktorat Jenderal Pajak. Universitas Gajah Mada. Tesis Yogyakarta: 2012

[2] Ahmad, Z., dan D. Taylor, Commitment to Independence by Internal Auditor: The Effects of Role Ambiguity and Role Conflict.Managerial Auditing Journal, Vol. 24,No. 9, pp. 899-925.

[3] Beauchamp, M.R., S.R. Bray, A. Fielding, dan M.A. Eys. (2004). A multilevel investigation of the relationship between role ambiguity and role efficacy in sport. Psychology of Sport and Exercise, Vol. 6, pp. 289-302.

[4] Buamonabot, Irfandi. (2012). Pengaruh Stres Peran Pada Kepuasan Kerja, dan Implikasinya Terhadap Intense Keluar Dengan Variabel Afek Positif Sebagai Pemoderasi. UniversitasGajah Mada, Yogyakarta.

[5] Effendi, M. Arief. (2006). Perkembangan Profesi Internal Audit Abad 21, Seminar / Kuliah Umum, Universitas International Batam.

[6] Hutami, Gartiria. (2012). Pengaruh Konflik Peran dan Ambiguiutas Peran Terhadap Komitmen Independensi Auditor Internal Pemerintah Daerah. Universitas Diponegoro, Semarang

[7] Koo, C.M. dan H.S. Sim. (1999). On The Role Conflict of Auditors in Korea. Accounting, Auditing, and Accountability Journal, Vol. 12, No. 2, pp. 206-219.

[8] Konsorium Organisasi Profesi Audit Internal. (2004). Standar Profesi Audit Internal.

[9] Muljono, Teguh Pudjo. (1994). Bank Auditing (Petunjuk Pemeriksaan Intern Bank).

[10] Mutchler, J.F. (2003). Independence and Objectivity: A Framework for Research Opportunities in Internal Auditing. The Institute of Internal Auditors, Altamonte Springs, FL.

[11] Nasution, Manahan. (2003). Sekilas Tentang Auditor Internal.Universitas Sumatera Utara, Sumatera Utara.

[12] Sarwono, Sarlito Wirawan. (2011). Teori-teori Psikologi Sosial. Grafindo Persada, Jakarta Sawyers. (2009). Internal Auditing 5th edition. Jakarta: Salemba Empat.

[13] Tugiman, Hiro. (1997). Standar Profesional Audit Internal. Kanisius, Yogyakarta. 